\title{
Review \\ Notes on Common Misconceptions in Microplastics Removal from Water
}

\author{
Pavel Krystynik $^{1,2, *}$, Katarina Strunakova ${ }^{3}$, Michal Syc ${ }^{1}\left[\right.$ and Petr Kluson ${ }^{1,3}$ \\ 1 Institute of Chemical Process Fundamentals, Academy of Sciences of the Czech Republic, Rozvojova 135, \\ 16502 Prague 6, Czech Republic; syc@icpf.cas.cz (M.S.); kluson@icpf.cas.cz (P.K.) \\ 2 Faculty of Environment, University of J. E. Purkyne, Pasteurova 3632/15, 40096 Usti nad Labem, Czech Republic \\ 3 Faculty of Science, Institute for Environmental Studies, Charles University, Benatska 2, \\ 12801 Prague 2, Czech Republic; katarina.strunakova@gmail.com \\ * Correspondence: krystynik@icpf.cas.cz; Tel.: +420-220-390-149
}

Citation: Krystynik, P.;

Strunakova, K.; Syc, M.; Kluson, P. Notes on Common Misconceptions in Microplastics Removal from Water. Appl. Sci. 2021, 11, 5833.

https://doi.org/10.3390/app11135833

Academic Editor: Rui C. Martins

Received: 25 May 2021

Accepted: 21 June 2021

Published: 23 June 2021

Publisher's Note: MDPI stays neutral with regard to jurisdictional claims in published maps and institutional affiliations.

Copyright: (c) 2021 by the authors. Licensee MDPI, Basel, Switzerland. This article is an open access article distributed under the terms and conditions of the Creative Commons Attribution (CC BY) license (https:// creativecommons.org/licenses/by/ $4.0 /)$.

\begin{abstract}
Occurrence of microplastics in the environment has become a serious problem with too many variables and unknowns regarding their relationship not only with human health but also with other parts of the environment. The toxic and ecotoxic properties are still a subject of interest and the scientific attitude to their threat is not unified. There are numerous review papers which report on microplastic particles occurrence in water, but similarly complex reviews on methods of their removal are not that frequent. This paper aims to provide a brief overview summarizing the most tested methods of microplastics removal and intends to critically evaluate them accordingly and advert to their discrepancies.
\end{abstract}

Keywords: microplastics; removal; degradation; separation; coagulation; filtration

\section{Introduction}

Over 350 billion tons of various plastic materials are annually produced worldwide [1] The most abundant plastics (manufactured and used) include polypropylene (PP), polyethylene (PE), polystyrene (PS), polyethylene terephthalate (PET) and polyvinyl chloride (PVC) [2]. Even the definition of microplastic particles seems to be very problematic, as they are often referred to as particles with dimensions less than $5 \mathrm{~mm}$, of various shapes [3]. Cole et al. broadened the definition due to main dimensions inconsistences and also defined "mesoplastics", to differentiate between particles visible to the human eye and those visible via microscopes, but it can be assumed that such definition might bring further incongruities [4]. Particles smaller than $100 \mathrm{~nm}$ are defined as nanoplastics [5]. However, accurate definitions of micro- and nanoplastic particles are still the subject of speculations [6].

Depending on their origin, microplastics can be primary or secondary:

- The primary ones were already produced in small dimensions for a specific purpose, most often as small particles in cosmetics [4].

- The secondary ones are formed by fragmentation of larger plastics through the action of UV radiation, mechanical forces, hydrolysis, or microbial processes that can happen in the aquatic environment [7].

Frias and Nash (2019) then provided their definition coming from broad inconsistencies in this topic: "Microplastics are any synthetic solid particle or polymeric matrix, with regular or irregular shape and with size ranging from $1 \mu \mathrm{m}$ to $5 \mathrm{~mm}$, of either primary or secondary manufacturing origin, which are insoluble in water."

Various views on microplastics in the environment are currently very popular among the scientific and even non-scientific public. It is very tough to be well versed in such a topic, as numerous studies on the occurrence of microplastics, which can be contradictory, have already been published (181 references on "microplastics in water", as entered, 2397 references on "microplastics" and "water", closely associated with one another, and 5059 
references on "microplastics" and "water" were present anywhere in the reference; Scifinder 25 May 2021). However, published data are not consistent and, thus, difficult to compare amongst themselves. It is then very problematic to compare processes for microplastics removal, because methods feasible for removal of $5 \mathrm{~mm}$ particles are different from those applied on $5 \mu \mathrm{m}$ particles.

Microplastics are considered inert and non-toxic to humans, or the effects on human health, have not been determined yet [8]. However, a toxic effect to aquatic organisms has already been proved $[9,10]$. The additives play a serious role as harmful products, when released from plastics during their degradation. This has been very well described for "macroparticles" and, in the case of microplastics degradation, the issue becomes more important again. The most discussed representatives might be Bisphenol A (BPA) and phthalates, which were being added as plasticizers to PVC [11]. In addition, microplastics might possess a surface area to which a wide range of contaminants may be adsorbed $[12,13]$. This aspect must be thoroughly investigated in order to confirm or exclude the possibility, but it can be assumed that microparticles of a certain weight would have larger surface area than macroparticles of the same weight. Mechanisms of contaminant adsorption were described by Joo et al., e.g., electrostatic repulsion, electrostatic interaction, hydrophobic interaction on the example of per-/poly-fluoralkylsubstances [14].

These include polycyclic aromatic hydrocarbons (PAHs), which are toxic and readily available for aquatic organisms and can further accumulate in food chains. Others may be persistent organic pollutants (POPs), pharmaceutical residues, pesticides, heavy metals and other potentially toxic substances from the surrounding aquatic environment [15]. Some of the released substances may act as endocrine disruptors $[16,17]$. Joo et al. also reported that microplastics may adsorb bacteria (antibiotic resistant bacteria) and viruses (coronavirus).

In recent years, microplastics occurrence in water and their removal has come to the forefront of research interest [17-25]. To give an example, three local drinking water treatment plants were tested for the presence of microplastic particles in water before and after treatment, with no special technologies for microplastics removal [26,27]. It has been pointed out that $95 \%$ of all microplastics in water are smaller than $10 \mu \mathrm{m}$ (the particles were divided into six fractions by total count: $0.2-1 \mu \mathrm{m} ; 1-5 \mu \mathrm{m} ; 5-10 \mu \mathrm{m} ; 10-50 \mu \mathrm{m} ; 50-100 \mu \mathrm{m}$; $>100 \mu \mathrm{m})$. The most dominating representatives were PET, PP and PE and the dominating forms were fragments of undefined shapes and fibres. The removal efficiency of treatment processes in monitored drinking water treatment plants was $83 \%$ on average. According to absolute concentrations of microplastics before and after treatment (3605 \pm 497 particles $\mathrm{L}^{-1} ; 628 \pm 28$ particles $\mathrm{L}^{-1}$ ) and considering no specialised method for their removal, a significant decrease was observed. However, space for improvement still exists.

Another study of the same research group investigated the influence of the size and shape of microplastics on their removal efficacy at various stages of water treatment in two drinking water treatment plants [28]. It was determined that coagulation/flocculation was not influenced by the size and shape of particles, while consecutive filtration through clay material improved removal of particles larger than $50 \mu \mathrm{m}$ and granular activated carbon improved removal of particles larger than $10 \mu \mathrm{m}$. The influence of their shape is yet to be determined. It was also shown that the most prevailing shape of microplastics was undefined fragment.

One of the important sources of microplastic particles in water is the washing of synthetic materials in households. This wastewater is further treated in wastewater treatment plants from where they can enter watercourses in nature [29-31]. All possible sources of microplastics in the environment are presented by $\mathrm{Xu}$ et al. in a well arranged way. The authors compare distribution of microplastics in different urban environments around the world and they conclude that microplastic may form an internal circulation, where human beings and aquatic organisms are continuously exposed to them [32].

Talvitie et al. (2017) have investigated how many microplastics can be captured by different wastewater treatment plant processes (membrane bioreactor as representative of primary stage treatment; filtrations and flotation as representatives of tertiary treatments). The device containing the membrane bioreactor was able to remove up to $99 \%$ of microplas- 
tics, the rapid sand filter $97 \%$, flotation removed $95 \%$ of particles and the disc filter $40-98 \%$ of contained microplastics [29]. This is seemingly a very nice result; however, the major drawback of this study was the range of detected microparticles-particles smaller than $20 \mu \mathrm{m}$ were not detected. Mintenig et al. [33] studied the presence of microplastics in drinking water originating from groundwater and determined the content of microplastics was only 0.7 particles per $\mathrm{m}^{3}$. However, this may be due to the fact that, again, the lower limit of the measurements was $20 \mu \mathrm{m}$. Oßmann et al. [34] determined microplastic particles in more than 30 samples of bottled water. Samples in glass bottles contained 2649-2857 particles $\mathrm{L}^{-1}$ and samples in PET bottles 6292-10,521 particles $\mathrm{L}^{-1}$. The authors also identified additives, such as pigment (from bottle labelling) or tris(2,4-di-tertbutylphenyl)phosphite (from the bottle material itself). Both in PET and glass bottles they found out that $90 \%$ of microplastic particles were smaller than $5 \mu \mathrm{m}$ and $40 \%$ were smaller than $1.5 \mu \mathrm{m}$ [34]. The authors correctly pointed out that a thoroughgoing analysis of particles smaller than $1 \mu \mathrm{m}$ is crucial in order to evaluate the number of particles that can be ingested and to determine their possible toxicological effect.

One can expect that what is suitable for microparticles with $\mathrm{mm}$ dimensions is not applicable for particles with $\mathrm{nm}$ dimensions. A simple comparison between published studies is therefore hardly feasible and a more complex approach is needed. This manuscript summarizes the most important methods applied for microplastic particles removal and evaluates them.

\section{Considerations}

Microplastics in the environment are a complex problem with no simple solution. The best way to eliminate their impact on the environment is to prevent their release into it. The sources of microplastics can be found in different areas of life and there are many types of plastics in many applications. Figure 1 summarizes the origin of microplastics according to their polymer type, use and percentage of total amounts.

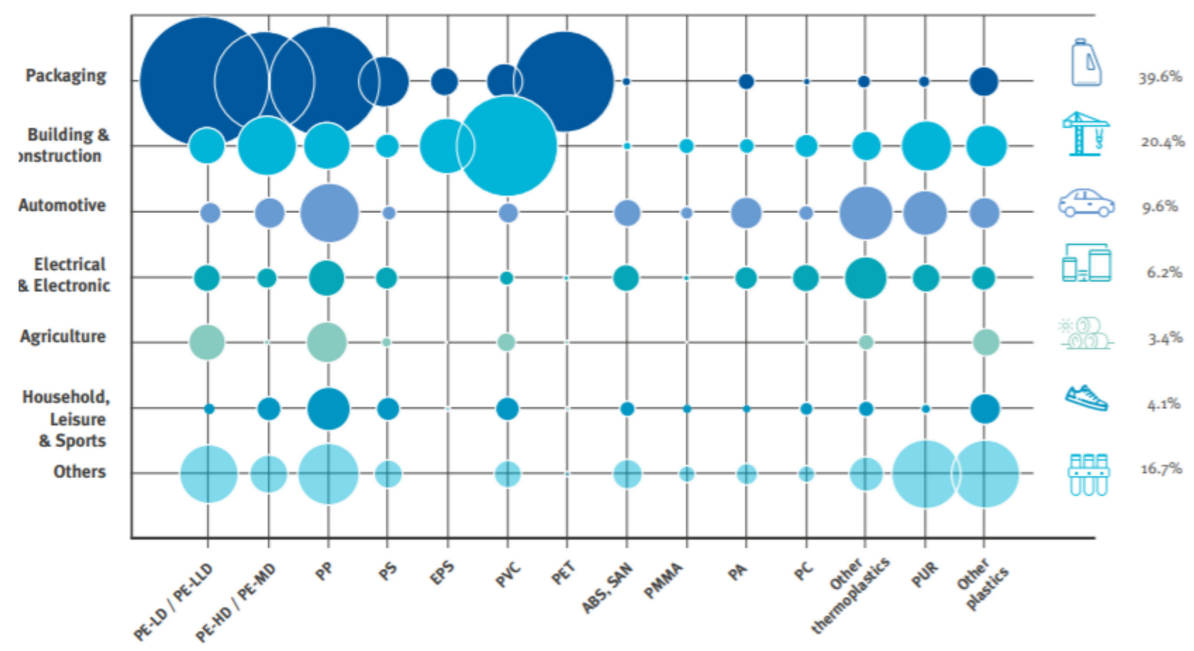

Figure 1. Percentual share of polymer types contributing to microplastic formation [35].

As already mentioned above, there is a broad spectrum of methods (classical and special) that could be tested and used for their removal. The text summarizes the most investigated methods applied for microplastics elimination. It is shown that literature data are quite problematic, because microplastic is a term with broad definition. Studies are focused on various dimensions of particles, thus generalization of results is rather problematic.

Filtration might be one of the most effective methods of microplastic particles removal due to its simple experimental arrangement, requirement of no special apparatuses and simple practicability. Of course, it cannot be used for all sizes of microparticles-especially $\mathrm{nm}$ dimensions would cause serious troubles with a pressure drop, the filtration barrier can be easily clogged and the need for replacement would occur quite often. Its fouling 
due to quick blockage and inability to be reused can also play an important role. These reasons may impede wider extension of microplastic filtration in practice, because the size of microparticles differs a lot.

Large particles $(\mathrm{mm})$ would undergo mechanical surface abrasion, making them different from smooth surface. This can result in an increase of hydrophobicity of surface, which enables adsorption of organic micropollutants. Such effect was observed during ozonation of PE particles [22]. In addition, the effect of their shape on their removal must be properly addressed, as mentioned by Pivokonský et al. (i.e., filtration of fibres would be more feasible than filtration of spheres, etc.) [28]. Another problem connected with microplastic particles is their inability to be settled; zeta potential would help with this respect, because this parameter provides comparable results in a dispersed environment and it is easily reproducible and such results could be comparable between various case studies. An observable decrease in microparticles in volume would result in an observable change in zeta potential value [36].

Another aspect is the determination of acceptable concentration of microparticles in water. Their toxic properties are still a big unknown; on the other hand, surface morphological changes may increase ability of organic micropollutants adsorption. With such aspect, it would be very difficult to estimate the safe concentration of microparticles in water.

The microplastic problem should be considered a complex issue, where prevention is much more relevant than solution of consequences. If we consider that microplastic origin lies in a PET bottle floating on the sea surface, there is still long pathway from the bottle to micro-particles. It is therefore advantageous to collect large particles, or, even better, not to throw them away. This is, however, a problem of the human population that does not have simple solution in prevention. As a result, these methods of microparticles removal have to be developed and investigated. The idea of this communication is to provide an overview on the most used methods and assess them.

\section{Microplastics Removal from Water}

The text below focuses on methods (destructive and non-destructive) of microplastic removal. All methods are assessed according to their particular use. The generalized simplified summary of methods is provided in Table 1. It must be noted that a simple comparison of the methods in the table is almost impossible. Every method has many special modifications that can take advantage over its basic variant.

Table 1. Groups of methods applicable on microplastics removal.

\begin{tabular}{ccccc}
\hline & $\begin{array}{c}\text { Energetically } \\
\text { Expensive }\end{array}$ & $\begin{array}{c}\text { Applicable on } \\
\text { Particle Size }\end{array}$ & $\begin{array}{c}\text { Removal via } \\
\text { Separation }\end{array}$ & $\begin{array}{c}\text { Removal via } \\
\text { Destruction }\end{array}$ \\
\hline Coagulation/flocculation & $\mathrm{No}$ & $\mathrm{mm}-\mu \mathrm{m}$ & Yes & No \\
Degradation (e.g., photo) & Yes & $\mathrm{nm}$ & No & Yes \\
Separation/flotation & $\mathrm{No}$ & $\mathrm{mm}-\mu \mathrm{m}$ & Yes & No \\
Separation/filtration & $\mathrm{No}$ & $\mathrm{mm}-\mu \mathrm{m}$ & Yes & No \\
\hline
\end{tabular}

\subsection{Coagulation/Flocculation}

Coagulation/flocculation is a chemical-based water treatment method used for the removal of dissolved or colloidal particles from water before phase separation (sedimentation, filtration). Coagulation is a process based on charge neutralization (the negative charge of suspended particles is neutralized by a positively charged coagulant), leading to the formation of insoluble aggregates (flocs). Flocculation is a process stage of coagulation at which gentle agitation is applied to boost the particles aggregation. This leads to the formation of large agglomerates that can already be well separated via sedimentation or filtration [37].

Several studies have focused on microplastic particles removal from water via coagulation. Ma et al. investigated coagulation of $\mathrm{PE}$ microparticles combining with ultrafiltration $\left(\mathrm{FeCl}_{3} \cdot 6 \mathrm{H}_{2} \mathrm{O}\right.$ and $\mathrm{AlCl}_{3} \cdot 6 \mathrm{H}_{2} \mathrm{O}$ used as coagulating agents). It was observed that aluminium 
salts were more suitable for the removal of PE particles. The smaller the PE particles, the higher the removal efficiency. This was explained via the zeta potential values of flocs and PE microparticles-zeta potential of Al flocs was at positive values $(0.52 \pm 0.14 \mathrm{mV})$, while zeta potential of $\mathrm{PE}$ microplastic particles was negative, at $\mathrm{pH} \geq 4$. Therefore, easier capture of smaller microparticles in coagulated flocs and their consequent removal with separated sludge occurred. The highest removal efficiency achieved was 37\% for particles smaller than $0.5 \mathrm{~mm}$. However, this efficiency was increased to $61 \%$ after the addition of $15 \mathrm{mg} / \mathrm{L}$ of anionic PAM (polyacrylamide) [38]. At neutral $\mathrm{pH}$, positively charged flocs were formed; anionic PAM therefore increased removal efficiency via charge neutralization. The removal efficiency increase caused by the addition of PAM was attributed to denser flocs formation, compared to the flocs formed without the addition of PAM. It resulted in increased adsorption capacity via stronger bridging effects and stronger sweep flocculation. The same phenomenon was observed in another study by the same research group [39]. Subsequently, the PE particles were completely removed by ultrafiltration through a membrane (pore size of $30 \mathrm{~nm}$ ), where the particles coagulated with aluminium salts slightly clogged the membrane. Another positive effect was observed by Skaf et al., where microplastics removal was enhanced by the presence of an anionic surfactant, but nonionic surfactant lead to worse removal efficiency [36]. In addition, a negative effect of nonionic surfactants was observed by Xia et al. The authors determined that the presence of nonionic surfactants helps microplastic particles to "stealth" before aluminum flocs during the coagulation process [40].

Coagulation processes are often combined with sand filters and other water treatment techniques that enhance microplastics removal efficiency [28,41]. It was described that coagulation/flocculation methods might be sufficiently efficient in microplastics removal; however, no model solution studies are presented. These cases described real effluents treated in WWTPs (wastewater treatment plants). Membrane filtrations might be a very efficient method with absolute removals, but they have very limited capacity; further, the cost of membranes operation would be unbearably high. In addition, a mutual comparison between two studies is impracticable, because each WWTP treats wastewater with different physical-chemical properties and the concentration of contaminants (including microplastics) is "unique" for every one of them.

Rajala et al. investigated removal of microplastic particles via coagulation followed by sedimentation with spherical polystyrene particles of two diameters, $1 \mu \mathrm{m}$ and 6.3 $\mu \mathrm{m}$. Ferric chloride, polyaluminium chloride and polyamine were compared and the highest removal efficiency was achieved with ferric chloride and polyaluminium chloride (up to 99\%) [42]. Hidayaturrahman and Lee tested the removal of microplastic $(<65 \mu \mathrm{m})$ particles at different stages of tertiary treatment in WWTPs and the results were compared with the primary and secondary treatment stages. It was determined that the primary and secondary stages were able to remove $75-92 \%$ of microplastic particles. However, considering the scale of water treated in WWTPs, a large number of microplastics was still present in water [43]. Aluminum coagulation was combined with different tertiary treatment technologies (ozonation, membrane disc-filter and rapid sand filter) and it was found out that such combination helped to increase the removal efficiency exceeding $99 \%$. Without application of additional tertiary treatment technologies, removal efficiency via coagulation was up to $95 \%$.

The positive effect of coagulant dosing enhancing microplastic particles removal was also confirmed [44]. It was reported that weathered microparticles revealed higher removal efficiency via coagulation and flocculation than fresh particles, due to changes on their surface roughness [45]. Aluminum coagulation is reported to be more efficient and studies on iron coagulation are not as intensively reported as aluminum coagulation. The reason might be in the different character of the sludge. Aluminum sludge contains more water than Fe sludge and that may be the reason why microplastic particles are better removed (not only adsorption on sludge surface but also water volume capture). 
Perren, Wojtasik and Cai focused on the removal of PE beads (300-355 $\mu \mathrm{m})$ from fresh water using electrocoagulation with aluminum electrodes. The authors tested various process parameters for the best performance of electrocoagulation and they achieved more than $99 \%$ removal efficiency at a $\mathrm{pH}$ of $7.5, \mathrm{NaCl}$ concentration of $2 \mathrm{~g} / \mathrm{L}$, current density $=11 \mathrm{~A} / \mathrm{m}^{2}$ and time of reaction of $60 \mathrm{~min}$ [46]. The authors do not report on coagulant dose, as this is the crucial parameter during coagulation studies. They put dose of coagulant in relation with current density, but it must be given in relation with current intensity. Current intensity is the parameter to be calculated with Faraday's Law. Another study that focused on the removal of microplastic particles via electrocoagulation as a consecutive step of sewage water treatment plants was made by Kim and Park. They focused on the removal of various types of PTFE plastics using an aluminum electrode. The authors achieved more than $90 \%$ removal efficacy by electrocoagulation of particles that could not be removed with other methods [47].

Electrocoagulation is considered an alternative to standard chemical coagulation with significantly reduced use of chemicals, because the coagulating chemical is replaced by an electrochemical substitute in the form of a sacrificial electrode [48].

\subsection{Degradation}

Degradation is defined as a process that leads to the deterioration of some of the physical properties of polymers. It may affect thermal stability, optical and mechanical properties, or crystallinity $[49,50]$. In the marine environment, mechanical degradation processes are facilitated by the action of waves, sand or other sediments [51]. Particles floating on the surface are exposed to sunlight and are subject to change due to UV radiation and oxidizing conditions of the atmosphere. In contrast, in deeper waters, where there is less radiation and oxygen, these abiotic processes are slower [52]. Biological activity is also rather negligible in deep oceans with reduced biodiversity. In less deep waters, many autotrophic, heterotrophic and symbiotic organisms have been found on the surface of microparticles, which play an important role in the degradation of these materials [53]. It could be presumed that biodegradability of microplastics depends on their material the same way as large plastic particles [54].

Not only a model solution in fresh water is missing, but seawater is a completely different environment and it is very problematic to predict the course of the process. The irradiation intensity changes with depth and the amount of dissolved oxygen also differs with depth, therefore simulation of such phenomena in laboratory conditions is crucial and necessary to conduct.

Additionally, there are studies that deal with various degradation ways of macroparticles of plastics. The main types include photo-oxidative degradation (photochemical and photocatalytic). There are also other techniques, such as thermal and mechanical-chemical degradation, ozone degradation, catalytic degradation and biodegradation. Partial change in their chemical structure, surface aging, weathering, surface properties change and loss of molecular weight have been proved, but complete removal via degradation is still a subject of research [45,55-58]. The first study on the complete mineralization of polystyrene microparticles appeared very recently, thus potential for their complete removal from water exists. The degradation was confirmed using in situ DRIFTS and mass spectrophotometry via formation of hydroxyl, carbonyl and carbon-hydrogen groups. Their presence was understood as evidence of polystyrene degradation [59].

The paper focuses on the photochemical, photocatalytic and ozonation degradation methods. They do not require special treatment and can be applied directly in water streams. Furthermore, they can be sequentially placed right after common water treatment methods. Thermal degradation requires the collection and separation of microparticles from water and their consequent transfer to a degradation reactor. Biodegradation does not seem to be an appropriate option, as biodegradation of plastic microparticles is reported to last days and weeks [60-65]. 


\subsubsection{Photochemical Degradation}

Photochemical degradation is a process in which the material undergoes degradation induced by UV light. UV radiation can cause photooxidative breaking of molecule chains and production of radical species, leading to change in mechanical and chemical properties of the irradiated material [66].

Photochemical degradation of plastic materials is a well described process $[49,67,68]$. It is considered to be one of the most efficient ways of degrading polymers. It takes place under the influence of irradiation of different wavelengths, where each polymer is most sensitive to a different wavelength [69]. During degradation, polymers change their mechanical and optical properties, they become more brittle and less elastic. There is also often a change in colour, when plastics begin to turn yellow.

Some authors investigated the effect of UV radiation on the thermoplastic polyester elastomer in an aqueous environment and in a water-free environment. Wavelengths shorter than $310 \mathrm{~nm}$ proved to be the most effective, because these wavelengths have enough energy to cause scission of polymer chains, forming esters and aldehydes. The presence of water caused the formation of a gel mass from the original polymers [70]. Furthermore, changes in the behaviour of low-density polyethylene (LDPE) under UV radiation were studied. Changes in the extensibility of LDPE in two environments-seawater and air-were monitored for one year. The study showed that photodegradation in the aquatic environment is much slower, which was explained by lower average temperatures [71].

Tribedi and Dey investigated the effect of LDPE pre-oxidation in soil induced by UV radiation in order to promote its biodegradation. It has been shown that UV-treated LDPE revealed better degradation efficiency than the ones that were not UV-treated [72]. The problematic comparison of different environments influencing the degradation of plastics is insufficient - there are just two environments to be compared (freshwater-air or seawater-air). Directly comparable data are unavailable and a proper comparison study should contain seawater- and freshwater-air environments. L. Zhu et al. observed the degradation of PE, PP and PS in seawater upon simulated sunlight (see Figure 2) [73]. The degradation was proved via surface changes (fragmentation, surface changes and alteration of the colour) and the increase in dissolved organic carbon (DOC) concentration in treated seawater. DOC is quantified as the organic carbon that passes through a submicron filter [74]. Releasing DOC consequently affected microbial activity in seawater.

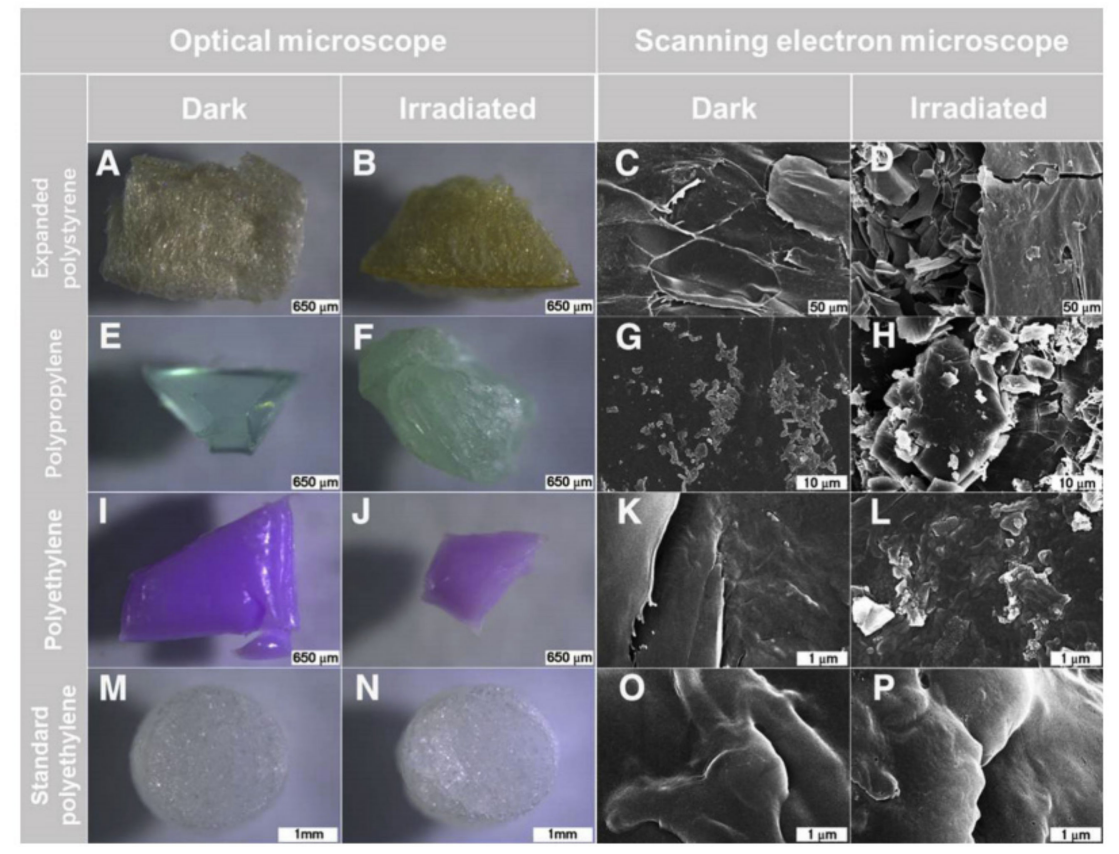

Figure 2. Pictures of investigated microparticles (L. Zhu et al. (2020)). Copyright available. 
Other studies mostly dealt with the degradation of PVC $[75,76]$, which constitutes the most commonly used plastics in everyday life. The aim of these studies was to find out how polymers were degraded upon external influences (temperature, radiation, air and humidity) and whether these influences shorten their durability. The authors concluded that better reproduction of natural weathering in laboratory conditions is achieved during experiments where water is periodically sprayed on exposed material (this simulates natural air humidity).

Mackul'ak et al. investigated PVC granules (diameter $4 \pm 2 \mathrm{~mm}$ ) degradation by Fenton reaction. It was demonstrated that Fenton treatment enhanced the formation of PVC degradation products (lower molecular weight fragments) that were further degraded by anaerobic digestion [77]. The effects of UV radiation are not much studied in the aquatic environment, but rather in the atmospheric environment. The future approach must be focused on the aquatic environment.

\subsubsection{Photocatalytic Degradation}

In the context of this communication, photocatalytic degradation is similar to photochemical degradation. Under certain conditions, it may result in the deterioration of some of the physical properties of polymers. However, for an effective process, a photocatalyst has to be employed. A photocatalyst is defined as "a material which absorbs light to bring it to higher energy level and provides the energy to a reacting substance to make a chemical reaction occur" [78]. In general, a photocatalyst yields reactive species upon UV irradiation, causing degradation of illuminated material.

A study on high-density polyethylene (HDPE) microparticles (0.7-1 mm) degradation using a protein-based porous $\mathrm{N}-\mathrm{TiO}_{2}$ semiconductor was performed and implicated that a potential for microplastic photocatalytic elimination exists. The advantage of proteinbased catalysts is the reduction of the $\mathrm{TiO}_{2}$ bandgap from $3.3 \mathrm{eV}$ to $2.9 \mathrm{eV}$. This bandgap drop enhances catalyst utilization upon visible light, absorbing photons at $427 \mathrm{~nm}$ [79]. This was followed by a study using a protein-derived $\mathrm{C}, \mathrm{N}-\mathrm{TiO}_{2}$ semiconductor in form of colloidal nanoparticles in aqueous environment and the combined effect of $\mathrm{pH}$ and temperature was investigated, in order to find optimal conditions. A low $\mathrm{pH}$ improved the interaction between the colloidal nanoparticles of the catalyst and microplastic particles; a low temperature increased the surface area via fragmentation, enhancing the interaction with catalyst nanoparticles [80]. These results were supported by an upcoming study performed by a similar research group [81].

Another study was focused on the degradation of LDPE in a water environment utilizing visible light and $\mathrm{ZnO}$ nanorods as a catalyst. The degradation of microplastic particles was monitored by FTIR and the formation of lower molecular weight compounds was detected [82]. This study provides valuable observations; it shows that such method can be an ideal way to follow the degradation mechanism, due to its high effectivity and reliability. The degradation was indicated by the formation of carbonyl and vinyl groups. $\mathrm{Xu}$ et al. also tested a $\mathrm{ZnO}$-based photocatalyst for microplastic polyethylene degradation. They also combined the method with coagulation as a "mainstream technology" for microplastics removal [32]. They concluded that none of these methods are capable of complete microplastics removal themselves, however, their combination may become a future development trend. $\mathrm{ZnO}$ photocatalytic abilities upon visible light in surface degradation changes of LDPE was confirmed by Tofa et al. $\mathrm{ZnO}$ was supported by $\mathrm{Pt}$ nanorods which were reported as efficient photocatalysts for LDPE degradation in a water environment [83].

A comparative study on degradation and mineralization of $C^{14}$-PS nanoparticles $(<1 \mu \mathrm{m})$ in water and air was performed upon UV-C irradiation. The authors found out that mineralization in water was significantly more efficient than mineralization in air. The phenomena were attributed to the water environment that enabled the formation of alkyl radicals at $254 \mathrm{~nm}$ and their further transformation towards peroxy- and alkoxyradicals, due to the presence of dissolved oxygen. They were further transformed via 
acetophenone and ketones towards ending products $\left(\mathrm{CO}_{2}\right.$ and $\left.\mathrm{H}_{2} \mathrm{O}\right)$. Proposed mechanism is given on Figure 3 [84]. This study provides a mechanism of PS degradation based on its chemical nature and, due to lack of such studies, provides one of the first theories of such nanoparticles degradation. It must also be noted that such mechanisms probably would not work for microparticles with units of hundreds and thousands $\mu \mathrm{m}$ dimensions.

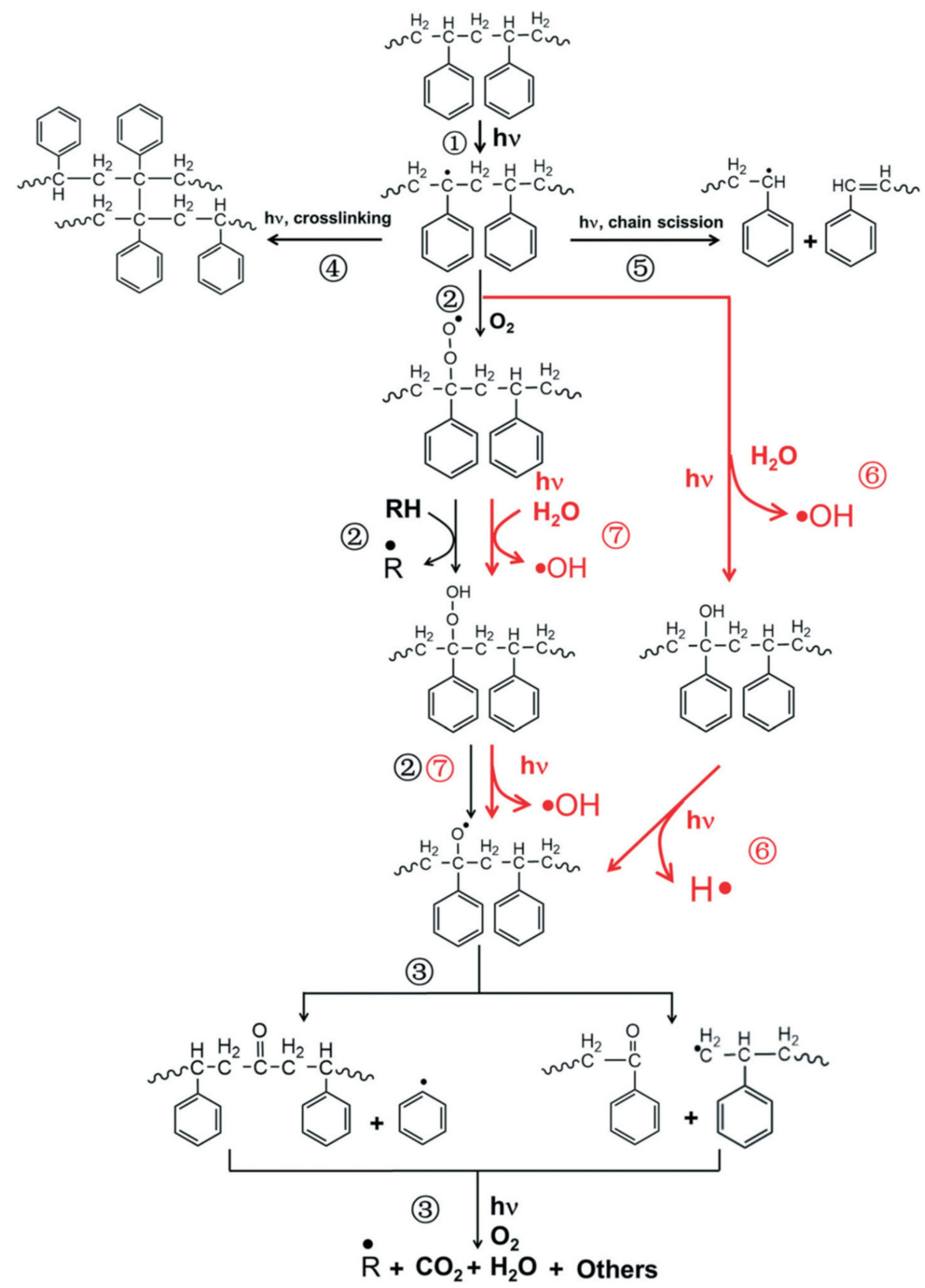

Figure 3. Proposed pathway of PS nanoplastics UV degradation in water (adapted from Tian et al. 2019, copyright available).

It must be also pointed out that such scenario with polystyrene particles is very likely to happen. PS is widely used as insulation of buildings and the use of such material is therefore very broadened. Cutting PS in compact blocks on site causes the release of a high number of PS spheres that can partially degrade upon sunlight, wash away with rainwater and, thus, spread in the environment.

The toxicity of by-products formed during photochemical and photocatalytic oxidation strongly depends on the polymer origin. For example, it was reported that products of photochemical oxidation of PP microplastics reveal low toxicity to humans and to the living 
species in the aquatic environment [85]. The issue of the formation of toxic by-products occurring during microplastic degradation has not been adequately treated yet. Serious attention is needed, here, in future [65]. However, some clear evidence is already available. Schiavo et al. attributed the toxicity increase to the release of heavy metals from the surface during microplastic degradation [86]. Adsorption of heavy metals and other common pollutants on the microplastics surface has been already described [87-92]. The negative role of the release of toxic elements and substances during microparticles degradation can be considered indisputable [93].

\subsubsection{Ozonation}

Ozonation is defined as a method leading to the degradation of the exposed material via ozone formation. Ozone molecules act as a reactive species, attacking bonds in organic molecules [49].

Ozonation is often applied on various pollutants removal from water [94-96]. However, these and other studies have a major drawback — they only study the effect of ozone as gas on the surface of plastic material. On the other hand, it is expected that plastic materials will undergo degradation using the ozonation process [97], but an aquatic environment will reflect a different behaviour, compared to an atmospheric environment.

Eitzen et al. [98] studied ozonation for the preparation of a model microplastic solution (PS, 1-200 $\mu \mathrm{m}$ ), because, when a solution of microplastics in water is being prepared, microparticles tend to aggregate and ozone dissolution helps to separate them. However, an increase in DOC (dissolved organic carbon) in the tested solution was observed, due to the partial oxidation of the PS surface yielding water-soluble oxidation products. Hidayaturrahman and Lee reported on the successful removal of microplastics (particles smaller than $1.2 \mu \mathrm{m}$ ) by ozonation on the tertiary stage of WWTPs and the efficiency was nearly $90 \%$, compared to removal by disc-filtration (79\%), or rapid sand filtration $(74 \%)$. The main disadvantages associated with ozone utilization are high energy consumption and formation of oxidizing organic by-products, which may reveal significant toxicity properties, e.g., carboxylic acids, or aldehydes [21]. Another recent study focused on pre-oxidative treatment of PE particles $(<0.5 \mathrm{~mm})$ by ozonation, hypochlorite and permanganate. It was shown that such pre-oxidation did not enhance the removal of microparticles by conventional drinking water treatment methods. On the other hand, the change in surface properties resulted in an increase in hydrophobicity; this resulted in better adsorption of hydrophobic organic micropollutants, which might cause a significant increase in particles toxicity [99].

Ozonation itself affects the surface properties of microparticles; however, very often, it contributes to an increase in toxic properties of the treated effluent. The size of microparticles also varies a lot (as for other methods), thus further research for better understanding is desired. On the other hand, for the preparation of a model solution, ozonation might help in disabling microparticles aggregation.

\subsection{Separation}

There are also methods that do not attempt to eliminate microplastic pollutants but intend to concentrate them and separate them from the effluent. Separated particles can be collected and transported to a municipal waste incineration plant.

Separation methods comprise density separation, vacuum filtration through a porous filter preceded by a sieve and sieving through a series of sieves with decreasing mesh sizes down towards $50 \mu \mathrm{m}$ [100]. Due to its relatively simple experimental arrangement, it can be considered a dominating method. However, nanoparticles would require very fine sieves, which can exhibit high pressure drop, quick clogging and requirement of frequent replacement and cleaning. Density separation might thus provide a more meaningful way.

Density separation was further developed (various extraction liquids, leaching in $\mathrm{H}_{2} \mathrm{O}_{2}$, flowing liquid, stirred-shaken sediment in gravitational or centrifugal field, in counter-current gas = foam flotation or elutriation) and high separation efficiency was achieved using a drum separator [101], or by electromagnetic density separation in a ferro 
liquid, which can change its density according to EM radiation (Kress and Franchetti [102]). Some of the plastics may have very similar density to water and that could be a major drawback of the practical application of such method.

The most often used separation technique, flotation, can be divided into three subgroups: selective flotation, froth flotation and hydrodynamic flotation [103].

Selective flotation in a standing liquid practically corresponds to density separation (the particles are divided according to different densities; sink-float method). The method is based on the separation of one kind of microplastic from a mixture of two or more. Separation is most often performed from sediments [104,105].

However, these methods reveal poor efficiency with particles smaller than $200 \mu \mathrm{m} \mathrm{[106].}$ HDPE particles $(100-850 \mu \mathrm{m})$ were tested for flotation in salty solutions in yields above $90 \%$ for high concentration samples and about $80 \%$ for low particle concentration samples [107]. The content of salt $(\mathrm{NaCl}, \mathrm{NaI})$ enhances the flotation of microparticles, because salt increases the difference between the density of water and microplastic particles. That provides an indication that the method would be feasible for salt water; however, not all types of microplastics would be possible to separate in practice-it would have to be carefully chosen materials with appropriate density, which would be different enough from water density.

High flotation yields were obtained using potassium ferrate; almost $100 \%$ yield was obtained for PC and PS particles of 2-4 mm [108]. Treatment with $\mathrm{K}_{2} \mathrm{FeO}_{4}$ changes surface properties and makes particles more floatable, due to increasing surface wettability. The question is, why particles of such size were not just filtered. Moreover, another aspect is that the water must be treated from $\mathrm{K}_{2} \mathrm{FeO}_{4}$. Selective flotation might be a very useful tool in the area of microplastic removal. The method is able to remove particles larger than $0.2 \mathrm{~mm}$ and, therefore, it can serve as the first significant method of microplastic reduction in the environment. These particles are easy to remove because they can still be visible to the human eye and, therefore, do not require a complicated membrane separation (membrane surface can be easily clogged and fouled by particles of smaller dimensions).

Froth flotation, where the particles are divided according to densities and air bubbles, uses the different hydrophobicity of the particle surfaces for their separation. Very high efficiency was achieved for removal of PC, PVC and PMMA particles in a solution containing potassium permanganate [109]. However, removal of potassium permanganate must be consequently dealt with.

Hydrodynamic flotation (elutriation) is a method where the distribution of particles according to density is supported by hydrodynamic flow. Initially, this method was used for the separation of microplastics from sediment by directing an ascending stream of water through the column, thereby inducing sediment fluidization. This technique was finally used for pretreatment to reduce the sample volume before density separation with sodium iodide solution and demonstrated great removal efficiency of PVC particles (100\%) and PVC fibers (98\%) [110]. Elutriation was also the basis of the air-induced overflow (AIO) technique, which involved fluidizing the sediment in an $\mathrm{NaCl}$ solution. Lighter particles moved faster to the top layer of the solution, which caused an $80 \%$ weight reduction of sediment right before density flotation in an NaI solution. Removal efficiency for $1 \mathrm{~mm}$ particles of PP, PVC, PET, PES and PUR varied between 91 and 99\% [111].

\subsection{Filtration}

Various types of filtration are the most widespread methods used in water treatment. Some of them may comprise rapid sand filtration, membrane filtration, activated carbon filtration, disc filtration, etc. There were also several studies focusing on removal of microplastic from water using filtration technologies and some of them were tested in real conditions in WWTPs.

Various tertiary treatment stage technologies in WWTPs were studied for the removal of microplastics from water. Two types of filtration, disc-filter and rapid sand filtration, were compared with membrane photoreactor on removal of particles of different material 
(PE, PES, etc., size > $20 \mu \mathrm{m}$ ) with more than 95\% removal efficiency. The major drawback of this study is the size of microplastic particles, because only particles larger than $20 \mu \mathrm{m}$ were determined [112]. Another study focused on smaller microplastic particles (size > 10 $\mu \mathrm{m})$ and tested removal efficiency via disc filtration. The results were evaluated in terms of number and mass of particles in WWTPs. It has been shown that disc filtration was able to remove almost $90 \%$ of microparticles [113].

Filtration is often part of coagulation/flocculation experiments (see Section 3.1) and Y. Zhang et al. [114] compared removal of microplastic particles (180 nm-125 $\mu \mathrm{m}, \mathrm{PE}, \mathrm{PS})$ via filtration and combined coagulation/flocculation/filtration process. The largest particles, in this study, were removed with almost absolute efficiency (106-125 $\mu \mathrm{m}$ with $>99 \%$ removal efficiency) and it was shown that the size of microplastic particles does not affect removal efficiency linearly; $180 \mathrm{~nm}$ particles were removed with nearly $99 \%$ efficiency, but particles with sizes of 10-20 $\mu \mathrm{m}$ were removed with less than $90 \%$ efficiency. This is explained by the possibility of smaller particles being more likely retained in filtration grains through particle attachment or diffusion. Ziheng Wang, Sedighi and Lea-Langton [115] compared rapid sand filtration (silica sand) with biochar filtration for removal of PS spherical microparticles $(10 \mu \mathrm{m})$ in a model solution. Two biochars of different origins (corn straw and hardwood), produced via a slow pyrolysis process at three temperatures $\left(300{ }^{\circ} \mathrm{C}, 400{ }^{\circ} \mathrm{C}\right.$ and $\left.500{ }^{\circ} \mathrm{C}\right)$, revealed higher removal efficiencies than sand filtration (more than $95 \%$ for biochars, compared to $60-80 \%$ for sand filter). It has also been reported that different mechanisms of immobilisation occur (biochars re-release less than $1 \%$ of retained microplastics by leaching, compared to $7 \%$ for sand filter).

Bayo, López-Castellanos and Olmos [116] investigated membrane bioreactor and rapid sand filtration for the removal of 14 different microplastics in the WWTP final effluent and studied removal efficiencies of different forms of microplastics (fibres, films, fragments and beads; $6.3-210 \mu \mathrm{m})$. The removal efficiencies of $79 \%$ for membrane reactor and $75 \%$ for rapid sand filtration were achieved. Based on these observations, the authors concluded that membrane bioreactor and rapid sand filtration are not better than conventional ones. Again, the main disadvantage of this study is the relative high dimensions of microplastic particles $(>6 \mu \mathrm{m})$. The influence of shape was not discussed. On the other hand, membrane bioreactor (pore size $<0.1 \mu \mathrm{m})$ was successfully used for the removal of PVC $(<5 \mu \mathrm{m})$ in a model solution, however, the presence of microplastic led to irreversible membrane fouling [117]. It has also been reported that PE microplastic particles can effectively be removed from water via membrane filtrations using PVDF with an average pore size of 30 nm [118]. Problems with membranes fouling were also described by Enfrin et al. [119]. Due to high pressure drop and immense price, it is unlikely that membrane filtrations would be applied in practice.

Separation via various filters may be driven by different mechanisms and not only the large surface area enhanced adsorption must occur. Detailed studies on mechanisms of particle/biochar filter interaction have been performed recently $[115,120]$. Three types of interactions were introduced: "stuck", "trapped" and "entangled". The first is described as a sieve, "microplastic particles are retailed in the gaps between the filter particles which are smaller than the particle size". The removal efficacy thus depends on the size of microplastic particles and filter particles (this mechanism is described for sand filter) $[112,115]$. The second is described for filters with highly porous structure, such as biochar or activated carbons. The microplastic particle enters slightly larger pores and remains there. The third is described for particles caught in microscopic holes on the surface of the filter material [115]. Sembiring et al. report on possible Van der Waals forces and physical interactions between microplastic particles and cloth filter, which is made of synthetic fibres [121].

Interactions of microplastic particles with membrane filters are usually described as size exclusion, hydrophobic interaction, biofilm formation and electrostatic interaction. At size exclusion, the size of pores is the dominating parameter-larger contaminants simply do not flow through and membrane fouling can easily occur [119]. Another mechanism 
is the hydrophobic interaction-it is described as the noncovalent force forming clusters of non-polar species on the non-polar surface of the membrane [14]. Biofilm formation is described as the interaction between microplastic particles and aquatic species (phytoplankton, microalgae) $[122,123]$. Electrostatic repulsion is defined as "a result of interaction between the electrical double layers surrounding particles or droplet" [124]. This phenomena can be influenced for removal efficiency and does not necessarily lead to membrane fouling - it can be controlled via $\mathrm{pH}$ of treated solution and adsorbed contaminants on the surface of microparticles [125]. Deeper discussions of such phenomena are beyond the scope of the paper.

\section{Conclusions}

Microplastic particles and methods of their removal from water are a challenging issue that will have to be solved in the near future. It has been shown that methods on removal of microplastics involve both separation and degradation. This communication summarized the most common published methods of microplastics removal and it assessed their applicability.

- Coagulation/flocculation provide promising results regarding microplastics removal from water. It has been shown the method is capable to remove particles with dimensions of $1 \mu \mathrm{m}$ and higher and can be applied directly in WWTPs, which is their real advantage.

- Degradation is a process that may lead to complete removal of microplastics from water via total decomposition. Photochemical, photocatalytic and ozone degradations were discussed. These methods trigger changes in the mechanical/chemical properties of microparticles that may ease their degradation. The size of treated particles does not seem to be limited-the reported removed dimensions were even below $1 \mu \mathrm{m}$. The most important drawback is the potential increase in treated effluent toxicity during the degradation process, as the surface can contain adsorbed contaminants of emerging concern that can be released from the surface during the degradation process.

- Separation methods, such as density separations or various types of flotation, often require the addition of other chemicals to the process. The reported treated size was limited to $50 \mu \mathrm{m}$ and higher.

- The advantage of filtration is its diversity, as many types of filtrations may be applied (sand filtration, biochar/activated carbon filtration, or membrane filtration). This method is also standardly applied directly in WWTPs. It seems that current versions of filters would not require special modification for microplastics removal. The main disadvantage of membrane filtration is its fast fouling with particles of $\mathrm{nm}$ dimensons.

Author Contributions: Conceptualization, P.K. (Pavel Krystynik) and K.S.; literature investigation, P.K. (Pavel Krystynik), K.S.; resources, P.K. (Pavel Krystynik); writing-original draft preparation, P.K. (Pavel Krystynik); writing-review and editing, P.K. (Petr Kluson), M.S.; supervision, P.K. (Petr Kluson); project administration, M.S. All authors have read and agreed to the published version of the manuscript.

Funding: The financial support of Technology Agency of the Czech Republic (Project No. SS02030008) and Ministry of Education, Youth and Sports of the Czech Republic (Project No. CZ.02.1.01/0.0/0.0/17_048/0007435) is gratefully acknowledged. Part of the work was provided by the research infrastructure NanoEnviCz (Project No. LM2018124).

Institutional Review Board Statement: Not applicable.

Informed Consent Statement: Not applicable.

Data Availability Statement: Presented data can be found in the studies "Zhu, L.; Zhao, S.; Bittar, T.B.; Stubbins, A.; Li, D. Photochemical dissolution of buoyant microplastics to dissolved organic carbon: Rates and microbial impacts. J. Hazard. Mater. 2020, 383, 121065."-Figure 2 and "Tian, L.; Chen, Q.; Jiang, W.; Wang, L.; Xie, H.; Kalogerakis, N.; Ma, Y.; Ji, R. A carbon-14 radiotracer-based 
study on the phototransformation of polystyrene nanoplastics in water: Versus in air. Environ. Sci. Nano 2019, 6, 2907-2917."-Figure 3. Copyright is provided.

Conflicts of Interest: The authors declare no conflict of interest.

$\begin{array}{ll}\text { Abbreviations } \\ \text { AIO } & \text { Air Induced Overflow } \\ \text { BPA } & \text { Bisphenol A } \\ \text { DOC } & \text { Dissolved Organic Carbon } \\ \text { DRIFTS } & \text { Diffuse Reflectance Infrared Fourier Transform Spectroscopy } \\ \text { EM } & \text { Electromagnetic (radiation) } \\ \text { FTIR } & \text { Fourier-Transform Infrared Spectroscopy } \\ \text { HDPE } & \text { High Density Polyethylene } \\ \text { LDPE } & \text { Low Density Polyethylene } \\ \text { PAHs } & \text { Polyaromatic hydrocarbons } \\ \text { PAM } & \text { Polyacrylamide } \\ \text { PE } & \text { Polyethylene } \\ \text { PES } & \text { Polyester } \\ \text { PET } & \text { Polyethylene terephthalate } \\ \text { PMMA } & \text { Polymethylmethacrylate } \\ \text { POPs } & \text { Persistent organic pollutants } \\ \text { PS } & \text { Polystyrene } \\ \text { PUR } & \text { Polyurethane } \\ \text { PVC } & \text { Polyvinylchloride } \\ \text { PVDF } & \text { Polyvinylidenefluoride } \\ \text { UV } & \text { Ultraviolet } \\ \text { WWTP } & \text { Waste Water Treatment Plant }\end{array}$

\section{References}

1. Bratovcic, A. Degradation of Micro-and Nano-Plastics by Photocatalytic Methods. J. Nanosci. Nanotechnol. Appl. 2019, 3, 1-9.

2. Rocha-Santos, T.; Duarte, A.C. A critical overview of the analytical approaches to the occurrence, the fate and the behavior of microplastics in the environment. TrAC Trends Anal. Chem. 2015, 65, 47-53. [CrossRef]

3. Thompson, R.C.; Moore, C.J.; Saal, F.S.V.; Swan, S.H. Plastics, the environment and human health: Current consensus and future trends. Philos. Trans. R. Soc. B Biol. Sci. 2009, 364, 2153-2166. [CrossRef] [PubMed]

4. Cole, M.; Lindeque, P.; Halsband, C.; Galloway, T.S. Microplastics as contaminants in the marine environment: A review. Mar. Pollut. Bull. 2011, 62, 2588-2597. [CrossRef] [PubMed]

5. Peiponen, K.E.; Räty, J.; Ishaq, U.; Pélisset, S.; Ali, R. Outlook on optical identification of micro-and nanoplastics in aquatic environments. Chemosphere 2019, 214, 424-429. [CrossRef] [PubMed]

6. Frias, J.P.G.L.; Nash, R. Microplastics: Finding a consensus on the definition. Mar. Pollut. Bull. 2019, 138, 145-147. [CrossRef] [PubMed]

7. Pico, Y.; Alfarhan, A.; Barcelo, D. Nano-and microplastic analysis: Focus on their occurrence in freshwater ecosystems and remediation technologies. TrAC Trends Anal. Chem. 2019, 113, 409-425. [CrossRef]

8. Lu, L.; Luo, T.; Zhao, Y.; Cai, C.; Fu, Z.; Jin, Y. Interaction between microplastics and microorganism as well as gut microbiota: A consideration on environmental animal and human health. Sci. Total Environ. 2019, 667, 94-100. [CrossRef]

9. Wang, X.; Zheng, H.; Zhao, J.; Luo, X.; Wang, Z.; Xing, B. Photodegradation Elevated the Toxicity of Polystyrene Microplastics to Grouper (Epinephelus moara) through Disrupting Hepatic Lipid Homeostasis. Environ. Sci. Technol. 2020, 54, 6202-6212. [CrossRef]

10. Xia, X.; Sun, M.; Zhou, M.; Chang, Z.; Li, L. Polyvinyl chloride microplastics induce growth inhibition and oxidative stress in Cyprinus carpio var. larvae. Sci. Total Environ. 2020, 716, 136479. [CrossRef] [PubMed]

11. Andrady, A.L. Microplastics in the marine environment. Mar. Pollut. Bull. 2011, 62, 1596-1605. [CrossRef] [PubMed]

12. Teuten, E.L.; Rowland, S.J.; Galloway, T.S.; Thompson, R.C. Potential for plastics to transport hydrophobic contaminants. Environ. Sci. Technol. 2007, 41, 7759-7764. [CrossRef] [PubMed]

13. Zhang, Z.; Chen, Y. Effects of microplastics on wastewater and sewage sludge treatment and their removal: A review. Chem. Eng. J. 2020, 382, 122955. [CrossRef]

14. Joo, S.H.; Liang, Y.; Kim, M.; Byun, J.; Choi, H. Microplastics with Adsorbed Contaminants: Mechanisms and Treatment. Environ. Chall. 2021, 3, 100042. [CrossRef]

15. Yuan, W.; Zhou, Y.; Chen, Y.; Liu, X.; Wang, J. Toxicological effects of microplastics and heavy metals on the Daphnia magna. Sci. Total Environ. 2020, 746, 141254. [CrossRef] 
16. Chen, Q.; Allgeier, A.; Yin, D.; Hollert, H. Leaching of endocrine disrupting chemicals from marine microplastics and mesoplastics under common life stress conditions. Environ. Int. 2019, 130, 104938. [CrossRef]

17. Silva, A.B.; Bastos, A.S.; Justino, C.I.; da Costa, J.P.; Duarte, A.C.; Rocha-Santos, T.A. Microplastics in the environment: Challenges in analytical chemistry-A review. Anal. Chim. Acta 2018, 1017, 1-19. [CrossRef]

18. Li, J.; Liu, H.; Paul Chen, J. Microplastics in freshwater systems: A review on occurrence, environmental effects, and methods for microplastics detection. Water Res. 2018, 137, 362-374. [CrossRef]

19. Sun, J.; Dai, X.; Wang, Q.; van Loosdrecht, M.C.M.; Ni, B.J. Microplastics in wastewater treatment plants: Detection, occurrence and removal. Water Res. 2019, 152, 21-37. [CrossRef]

20. Bui, X.T.; Vo, T.-D.; Nguyen, P.-T.; Nguyen, V.-T.; Dao, T.-S.; Nguyen, P.-D. Microplastics pollution in wastewater: Characteristics, occurrence and removal technologies. Environ. Technol. Innov. 2020, 19, 101013. [CrossRef]

21. Sol, D.; Laca, A.; Laca, A.; Díaz, M. Approaching the environmental problem of microplastics: Importance of WWTP treatments. Sci. Total Environ. 2020, 740, 140016. [CrossRef]

22. Wang, Z.; Lin, T.; Chen, W. Occurrence and removal of microplastics in an advanced drinking water treatment plant (ADWTP). Sci. Total Environ. 2020, 700, 134520. [CrossRef]

23. Ahmed, M.B.; Rahman, S.; Alom, J.; Hasan, S.; Johir, M.; Mondal, M.I.H.; Lee, D.-Y.; Park, J.; Zhou, J.L.; Yoon, M.-H. Microplastic Particles in the Aquatic Environment: A Systematic Review. Sci. Total Environ. 2021, 775, 145793. [CrossRef]

24. Bayo, J.; Olmos, S.; López-Castellanos, J. Assessment of Microplastics in a Municipal Wastewater Treatment Plant with Tertiary Treatment: Removal Efficiencies and Loading per Day into the Environment. Water 2021, 13, 1339. [CrossRef]

25. Fältström, E.; Olesen, K.B.; Anderberg, S. Microplastic Types in the Wastewater System-A Comparison of Material Flow-Based Source Estimates and the Measurement-Based Load to a Wastewater Treatment Plant. Sustainability 2021, 13, 5404. [CrossRef]

26. Novotna, K.; Cermakova, L.; Pivokonska, L.; Cajthaml, T.; Pivokonsky, M. Microplastics in drinking water treatment-Current knowledge and research needs. Sci. Total Environ. 2019, 667, 730-740. [CrossRef] [PubMed]

27. Pivokonsky, M.; Čermáková, L.; Novotna, K.; Peer, P.; Cajthaml, T.; Janda, V. Occurrence of microplastics in raw and treated drinking water. Sci. Total Environ. 2018, 643, 1644-1651. [CrossRef]

28. Pivokonský, M.; Pivokonská, L.; Novotná, K.; Čermáková, L.; Klimtová, M. Occurrence and fate of microplastics at two different drinking water treatment plants within a river catchment. Sci. Total Environ. 2020, 741, 140236. [CrossRef]

29. Talvitie, J.; Mikola, A.; Setälä, O.; Heinonen, M.; Koistinen, A. How well is microlitter purified from wastewater?-A detailed study on the stepwise removal of microlitter in a tertiary level wastewater treatment plant. Water Res. 2017, 109, 164-172. [CrossRef]

30. Magni, S.; Binelli, A.; Pittura, L.; Avio, C.G.; Della Torre, C.; Parenti, C.C.; Gorbi, S.; Regoli, F. The fate of microplastics in an Italian Wastewater Treatment Plant. Sci. Total Environ. 2019, 652, 602-610. [CrossRef]

31. Gies, E.A.; LeNoble, J.L.; Noël, M.; Etemadifar, A.; Bishay, F.; Hall, E.R.; Ross, P.S. Retention of microplastics in a major secondary wastewater treatment plant in Vancouver, Canada. Mar. Pollut. Bull. 2018, 133, 553-561. [CrossRef]

32. Xu, Q.; Huang, Q.-S.; Luo, T.-Y.; Wu, R.-L.; Wei, W.; Ni, B.-J. Coagulation removal and photocatalytic degradation of microplastics in urban waters. Chem. Eng. J. 2021, 416, 129123. [CrossRef]

33. Mintenig, S.M.; Löder, M.G.J.; Primpke, S.; Gerdts, G. Low numbers of microplastics detected in drinking water from ground water sources. Sci. Total Environ. 2019, 648, 631-635. [CrossRef]

34. Oßmann, B.E.; Sarau, G.; Holtmannspötter, H.; Pischetsrieder, M.; Christiansen, S.H.; Dicke, W. Small-sized microplastics and pigmented particles in bottled mineral water. Water Res. 2018, 141, 307-316. [CrossRef]

35. PlasticEurope: Plastics-The Facts 2020. 2020. Available online: https://www.plasticseurope.org/en/resources/publications/43 12-plastics-facts-2020 (accessed on 13 May 2021).

36. Skaf, D.W.; Punzi, V.L.; Rolle, J.T.; Kleinberg, K.A. Removal of micron-sized microplastic particles from simulated drinking water via alum coagulation. Chem. Eng. J. 2020, 386, 123807. [CrossRef]

37. Zhao, C.; Zhou, J.; Yan, Y.; Yang, L.; Xing, G.; Li, H.; Wu, P.; Wang, M.; Zheng, H. Application of coagulation/flocculation in oily wastewater treatment: A review. Sci. Total Environ. 2021, 765, 142795. [CrossRef]

38. Ma, B.; Xue, W.; Hu, C.; Liu, H.; Qu, J.; Li, L. Characteristics of microplastic removal via coagulation and ultrafiltration during drinking water treatment. Chem. Eng. J. 2019, 359, 159-167. [CrossRef]

39. Ma, B.; Xue, W.; Ding, Y.; Hu, C.; Liu, H.; Qu, J. Removal characteristics of microplastics by Fe-based coagulants during drinking water treatment. J. Environ. Sci. 2019, 78, 267-275. [CrossRef]

40. Xia, Y.; Xiang, X.M.; Dong, K.Y.; Gong, Y.Y.; Li, Z.J. Surfactant stealth effect of microplastics in traditional coagulation process observed via 3-D fluorescence imaging. Sci. Total Environ. 2020, 729, 138783. [CrossRef]

41. Shahi, N.K.; Maeng, M.; Kim, D.; Dockko, S. Removal behavior of microplastics using alum coagulant and its enhancement using polyamine-coated sand. Process Saf. Environ. Prot. 2020, 141, 9-17. [CrossRef]

42. Rajala, K.; Grönfors, O.; Hesampour, M.; Mikola, A. Removal of microplastics from secondary wastewater treatment plant effluent by coagulation/flocculation with iron, aluminum and polyamine-based chemicals. Water Res. 2020, 183, 116045. [CrossRef] [PubMed]

43. Hidayaturrahman, H.; Lee, T.G. A study on characteristics of microplastic in wastewater of South Korea: Identification, quantification, and fate of microplastics during treatment process. Mar. Pollut. Bull. 2019, 146, 696-702. [CrossRef] 
44. Rezania, S.; Park, J.; Din, M.F.M.; Taib, S.M.; Talaiekhozani, A.; Yadav, K.K.; Kamyab, H. Microplastics pollution in different aquatic environments and biota: A review of recent studies. Mar. Pollut. Bull. 2018, 133, 191-208. [CrossRef]

45. Lapointe, M.; Farner, J.M.; Hernandez, L.M.; Tufenkji, N. Understanding and Improving Microplastic Removal during Water Treatment: Impact of Coagulation and Flocculation. Environ. Sci. Technol. 2020, 54, 8719-8727. [CrossRef] [PubMed]

46. Perren, W.; Wojtasik, A.; Cai, Q. Removal of Microbeads from Wastewater Using Electrocoagulation. ACS Omega 2018, 3, 3357-3364. [CrossRef] [PubMed]

47. Kim, K.T.; Park, S. Enhancing microplastics removal from wastewater using electro-coagulation and granule-activated carbon with thermal regeneration. Processes 2021, 9, 617. [CrossRef]

48. Tito, D.N.; Krystynik, P.; Kluson, P. Notes on process and data analysis in electro-coagulation-The importance of standardisation and clarity. Chem. Eng. Process. Process Intensif. 2016, 104, 22-28. [CrossRef]

49. Singh, B.; Sharma, N. Mechanistic implications of plastic degradation. Polym. Degrad. Stab. 2008, 93, 561-584. [CrossRef]

50. Anatolyevich Khaustov, I.; Ksenofontovich Bitukov, V.; Germanovich Tikhomirov, S.; Anatolyevich Khvostov, A.; Petrovich Popov, A. Control over the Process of Thermo-Oxidative Degradation of Polymers in a Solution. Mod. Appl. Sci. 2015, 9, 128-139. [CrossRef]

51. Coyle, R.; Hardiman, G.; Driscoll, K.O. Microplastics in the marine environment: A review of their sources, distribution processes and uptake into ecosystems. Case Stud. Chem. Environ. Eng. 2020, 2, 100010. [CrossRef]

52. Da Costa, J.P.; Santos, P.S.M.; Duarte, A.C.; Rocha-Santos, T. (Nano)plastics in the environment-Sources, fates and effects Sci. Total Environ. 2016, 566-567, 15-26. [CrossRef] [PubMed]

53. Zettler, E.R.; Mincer, T.J.; Amaral-Zettler, L.A. Life in the 'plastisphere': Microbial communities on plastic marine debris. Environ. Sci. Technol. 2013, 47, 7137-7146. [CrossRef] [PubMed]

54. Song, X.; Wu, X.; Song, X.; Shi, C.; Zhang, Z. Sorption and desorption of petroleum hydrocarbons on biodegradable and nondegradable microplastics. Chemosphere 2020, 273, 128553. [CrossRef]

55. Lang, M.; Yu, X.; Liu, J.; Xia, T.; Wang, T.; Jia, H.; Guo, X. Fenton aging significantly affects the heavy metal adsorption capacity of polystyrene microplastics. Sci. Total Environ. 2020, 722, 137762. [CrossRef] [PubMed]

56. Zhu, K.; Jia, H.; Sun, Y.; Dai, Y.; Zhang, C.; Guo, X.; Wang, T.; Zhu, L. Long-term phototransformation of microplastics under simulated sunlight irradiation in aquatic environments: Roles of reactive oxygen species. Water Res. 2020, 173, 115564. [CrossRef]

57. Naik, R.A.; Rowles, L.S.; Hossain, A.I.; Yen, M.; Aldossary, R.M.; Apul, O.G.; Conkle, J.; Saleh, N.B. Microplastic particle versus fiber generation during photo-transformation in simulated seawater. Sci. Total Environ. 2020, 736, 139690. [CrossRef] [PubMed]

58. Guo, X.; Wang, J. The chemical behaviors of microplastics in marine environment: A review. Mar. Pollut. Bull. 2019, 142, 1-14. [CrossRef]

59. Nabi, I.; Bacha, A.-U.; Li, K.; Cheng, H.; Wang, T.; Liu, Y.; Ajmal, S.; Yang, Y.; Feng, Y.; Zhang, L. Complete Photocatalytic Mineralization of Microplastic on TiO2 Nanoparticle Film. iScience 2020, 23, 101326. [CrossRef] [PubMed]

60. Zurier, H.S.; Goddard, J.M. ScienceDirect Biodegradation of microplastics in food and agriculture. Curr. Opin. Food Sci. 2021, 37, 37-44. [CrossRef]

61. Shabbir, S.; Faheem, M.; Ali, N.; Kerr, P.G.; Wang, L.F.; Kuppusamy, S.; Li, Y. Periphytic biofilm: An innovative approach for biodegradation of microplastics. Sci. Total Environ. 2020, 717, 137064. [CrossRef]

62. Chen, Z.; Zhao, W.; Xing, R.; Xie, S.; Yang, X.; Cui, P.; Lü, J.; Liao, H.; Yu, Z.; Wang, S.; et al. Enhanced in situ biodegradation of microplastics in sewage sludge using hyperthermophilic composting technology. J. Hazard. Mater. 2020, 384, 121271. [CrossRef]

63. Zhang, J.; Gao, D.; Li, Q.; Zhao, Y.; Li, L.; Lin, H.; Bi, Q.; Zhao, Y. Biodegradation of polyethylene microplastic particles by the fungus Aspergillus flavus from the guts of wax moth Galleria mellonella. Sci. Total Environ. 2020, 704, 1-8. [CrossRef]

64. Gong, J.; Kong, T.; Li, Y.; Li, Q.; Li, Z.; Zhang, J. Biodegradation of microplastic derived from poly(ethylene terephthalate) with bacterial whole-cell biocatalysts. Polymers 2018, 10, 1326. [CrossRef]

65. Du, H.; Xie, Y.; Wang, J. Microplastic degradation methods and corresponding degradation mechanism: Research status and future perspectives. J. Hazard. Mater. 2021, 418, 126377. [CrossRef] [PubMed]

66. Yousif, E.; Haddad, R. Photodegradation and photostabilization of polymers, especially polystyrene: Review. Springerplus 2013, 2, 1-32. [CrossRef] [PubMed]

67. Tyler, D.R. Photochemically degradable polymers containing metal-metal bonds along their backbones. Coord. Chem. Rev. 2003, 246, 291-303. [CrossRef]

68. Chalmers, J.M.; Meier, R.J. Chapter 10 Polymer Degradation and Oxidation: An Introduction. In Molecular Characterization and Analysis of Polymers; Chalmers, J.M., Meier, R.J., Eds.; Elsevier: Amsterdam, The Netherlands, 2008; Volume 53, pp. 387-450.

69. Andrady, A.L.; Hamid, S.H.; Hu, X.; Torikaid, A. Effects of increased solar ultraviolet radiation on terrestrial ecosystems. J. Photochem. Photobiol. B Biol. 1998, 46, 40-52. [CrossRef]

70. Nagai, Y.; Ogawa, T.; Nishimoto, Y.; Ohishi, F. Analysis of weathering of a thermoplastic polyester elastomer. II. Factors affecting weathering of a polyether-polyester elastomer. Polym. Degrad. Stab. 1999, 65, 217-224. [CrossRef]

71. Andrady, A.L. Weathering of polyethylene (LDPE) and enhanced photodegradable polyethylene in the marine environment. J. Appl. Polym. Sci. 1990, 39, 363-370. [CrossRef]

72. Tribedi, P.; Dey, S. Pre-oxidation of low-density polyethylene (LDPE) by ultraviolet light (UV) promotes enhanced degradation of LDPE in soil. Environ. Monit. Assess. 2017, 189, 624. [CrossRef] 
73. Zhu, L.; Zhao, S.; Bittar, T.B.; Stubbins, A.; Li, D. Photochemical dissolution of buoyant microplastics to dissolved organic carbon: Rates and microbial impacts. J. Hazard. Mater. 2020, 383, 121065. [CrossRef] [PubMed]

74. Dittmar, T.; Stubbins, A. 12.6-Dissolved Organic Matter in Aquatic Systems. In Treatise on Geochemistry, 2nd ed.; Holland, H.D., Turekian, K.K., Eds.; Elsevier: Amsterdam, The Netherlands, 2014; pp. 125-156. [CrossRef]

75. Hussain, I.; Hamid, S.H.; Khan, J.H. Polyvinyl chloride pipe degradation studies in natural environments. J. Vinyl Addit. Technol. 1995, 1, 137-141. [CrossRef]

76. Real, L.P.; Gardette, J.L.; Pereira Rocha, A. Artificial simulated and natural weathering of poly(vinyl chloride) for outdoor applications: The influence of water in the changes of properties. Polym. Degrad. Stab. 2005, 88, 357-362. [CrossRef]

77. Mackul'ak, T.; Takáčová, A.; Gál, M.; Marton, M.; Ryba, J. PVC degradation by Fenton reaction and biological decomposition. Polym. Degrad. Stab. 2015, 120, 226-231. [CrossRef]

78. Oshida, Y. 4-Oxidation and Oxides. In Bioscience and Bioengineering of Titanium Materials, 2nd ed.; Oshida, Y., Ed.; Elsevier: Amsterdam, The Netherland, 2013; pp. 87-115. [CrossRef]

79. Ariza-Tarazona, M.C.; Villarreal-Chiu, J.F.; Barbieri, V.; Siligardi, C.; Cedillo-González, E.I. New strategy for microplastic degradation: Green photocatalysis using a protein-based porous N-TiO 2 semiconductor. Ceram. Int. 2019, 45, 9618-9624. [CrossRef]

80. Ariza-Tarazona, M.C.; Villarreal-Chiu, J.F.; Hernández-López, J.M.; De la Rosa, J.R.; Barbieri, V.; Siligardi, C.; Cedillo-González, E.I. Microplastic pollution reduction by a carbon and nitrogen-doped TiO2: Effect of $\mathrm{pH}$ and temperature in the photocatalytic degradation process. J. Hazard. Mater. 2020, 395, 122632. [CrossRef]

81. Vital-Grappin, A.D.; Ariza-Tarazona, M.C.; Luna-Hernández, V.M.; Villarreal-Chiu, J.F.; Hernández-López, J.M.; Siligardi, C.; Cedillo-González, E.I. The role of the reactive species involved in the photocatalytic degradation of hdpe microplastics using c,n-tio2 powders. Polymers 2021, 13, 999. [CrossRef]

82. Tofa, T.S.; Kunjali, K.L.; Paul, S.; Dutta, J. Visible light photocatalytic degradation of microplastic residues with zinc oxide nanorods. Environ. Chem. Lett. 2019, 17, 1341-1346. [CrossRef]

83. Tofa, T.S.; Ye, F.; Kunjali, K.L.; Dutta, J. Enhanced visible light photodegradation of microplastic fragments with plasmonic platinum/zinc oxide nanorod photocatalysts. Catalysts 2019, 9, 819. [CrossRef]

84. Tian, L.; Chen, Q.; Jiang, W.; Wang, L.; Xie, H.; Kalogerakis, N.; Ma, Y.; Ji, R. A carbon-14 radiotracer-based study on the phototransformation of polystyrene nanoplastics in water: Versus in air. Environ. Sci. Nano 2019, 6, 2907-2917. [CrossRef]

85. Uheida, A.; Mejía, H.G.; Abdel-Rehim, M.; Hamd, W.; Dutta, J. Visible light photocatalytic degradation of polypropylene microplastics in a continuous water flow system. J. Hazard. Mater. 2021, 406, 124299. [CrossRef]

86. Schiavo, S.; Oliviero, M.; Chiavarini, S.; Manzo, S. Adverse effects of oxo-degradable plastic leachates in freshwater environment. Environ. Sci. Pollut. Res. 2020, 27, 8586-8595. [CrossRef] [PubMed]

87. Wang, F.; Wong, C.S.; Chen, D.; Lu, X.; Wang, F.; Zeng, E.Y. Interaction of toxic chemicals with microplastics: A critical review. Water Res. 2018, 139, 208-219. [CrossRef]

88. Tourinho, P.S.; Kočí, V.; Loureiro, S.; van Gestel, C.A.M. Partitioning of chemical contaminants to microplastics: Sorption mechanisms, environmental distribution and effects on toxicity and bioaccumulation. Environ. Pollut. 2019, 252, 1246-1256. [CrossRef] [PubMed]

89. Guo, X.; Chen, C.; Wang, J. Sorption of sulfamethoxazole onto six types of microplastics. Chemosphere 2019, 228, 300-308. [CrossRef]

90. Xu, P.; Ge, W.; Chai, C.; Zhang, Y.; Jiang, T.; Xia, B. Sorption of polybrominated diphenyl ethers by microplastics. Mar. Pollut. Bull. 2019, 145, 260-269. [CrossRef]

91. Liu, X.; Xu, J.; Zhao, Y.; Shi, H.; Huang, C.H. Hydrophobic sorption behaviors of 17B-Estradiol on environmental microplastics. Chemosphere 2019, 226, 726-735. [CrossRef]

92. Ricardo, I.A.; Alberto, E.A.; Júnior, A.H.S.; Macuvele, D.L.P.; Padoin, N.; Soares, C.; Riella, H.G.; Starling, M.C.V.; Trovó, A.G A critical review on microplastics, interaction with organic and inorganic pollutants, impacts and effectiveness of advanced oxidation processes applied for their removal from aqueous matrices. Chem. Eng. J. 2021, 424, 130282. [CrossRef]

93. Hamidian, A.H.; Ozumchelouei, E.J.; Feizi, F.; Wu, C.; Zhang, Y.; Yang, M. A review on the characteristics of microplastics in wastewater treatment plants: A source for toxic chemicals. J. Clean. Prod. 2021, 295, 126480. [CrossRef]

94. Ozen, B.F.; Mauer, L.J.; Floros, J.D. Effects of ozone exposure on the structural, mechanical and barrier properties of select plastic packaging films. Packag. Technol. Sci. 2002, 15, 301-311. [CrossRef]

95. Clough, R.L.; Gillen, K.T. Polymer degradation under ionizing radiation: The role of ozone. J. Polym. Sci. Part A Polym. Chem. 1989, 27, 2313-2324. [CrossRef]

96. Gatenholm, P.; Ashida, T.; Hoffman, A.S. Hybrid biomaterials prepared by ozone-induced polymerization. I. Ozonation of microporous polypropylene. J. Polym. Sci. Part A Polym. Chem. 1997, 35, 1461-1467. [CrossRef]

97. Chen, R.; Qi, M.; Zhang, G.; Yi, C. Comparative experiments on polymer degradation technique of produced water of polymer flooding oilfield. In Proceedings of the IOP Conference Series: Earth and Environmental Science, Harbin, China, 8-10 December 2017; Volume 113, p. 12208.

98. Eitzen, L.; Paul, S.; Braun, U.; Altmann, K.; Jekel, M.; Ruhl, A.S. The challenge in preparing particle suspensions for aquatic microplastic research. Environ. Res. 2019, 168, 490-495. [CrossRef] [PubMed] 
99. Shao, Y.; Zhou, X.; Liu, X.; Wang, L. Pre-oxidization-induced change of physicochemical characteristics and removal behaviours in conventional drinking water treatment processes for polyethylene microplastics. RSC Adv. 2020, 41488-41494. [CrossRef]

100. Rocha-Santos, T.A.; Duarte, A.C. Characterization and Analysis of Microplastics. In Characterization and Analysis of Microplastics, 1st ed.; Rocha-Santos, T.A.P., Duarte, A.C., Eds.; Elsevier: Amsterdam, The Netherlands, 2017; Volume 75.

101. Markauskas, D.; Kruggel-Emden, H.; Scherer, V. Numerical analysis of wet plastic particle separation using a coupled DEM-SPH method. Powder Technol. 2018, 325, 218-227. [CrossRef]

102. Kress, C.; Franchetti, M. Post-Consumer Plastic Sortation with the Use of Electromagnetic Separation Methods for Recycling. In Emerging Technologies, Proceedings of the ASME 2013 International Mechanical Engineering Congress and Exposition, San Diego, CA, USA, 15-21 November 2013; ASME: San Diego, CA, USA, 2013; Volume 11, p. V011T06A015. [CrossRef]

103. Wang, Z.; Taylor, S.E.; Sharma, P.; Flury, M. Poor extraction efficiencies of polystyrene nano- and microplastics from biosolids and soil. PLOS ONE 2018, 13, e0208009. [CrossRef] [PubMed]

104. Pagter, E.; Frias, J.; Nash, R. Microplastics in Galway Bay: A comparison of sampling and separation methods. Mar. Pollut. Bull. 2018, 135, 932-940. [CrossRef] [PubMed]

105. Ceccarini, A.; Corti, A.; Erba, F.; Modugno, F.; La Nasa, J.; Bianchi, S.; Castelvetro, V. The Hidden Microplastics: New Insights and Figures from the Thorough Separation and Characterization of Microplastics and of Their Degradation Byproducts in Coastal Sediments. Environ. Sci. Technol. 2018, 52, 5634-5643. [CrossRef]

106. Quinn, B.; Murphy, F.; Ewins, C. Validation of density separation for the rapid recovery of microplastics from sediment. Anal. Methods 2017, 9, 1491-1498. [CrossRef]

107. Sánchez-Nieva, J.; Perales, J.A.; González-Leal, J.M.; Rojo-Nieto, E. A new analytical technique for the extraction and quantification of microplastics in marine sediments focused on easy implementation and repeatability. Anal. Methods 2017, 9, 6371-6378. [CrossRef]

108. Wang, H.; Wang, J.; Zou, Q.; Liu, W.; Wang, C.; Huang, W. Surface treatment using potassium ferrate for separation of polycarbonate and polystyrene waste plastics by froth flotation. Appl. Surf. Sci. 2018, 448, 219-229. [CrossRef]

109. Wang, C.Q.; Wang, H.; Huang, L.-L. A novel process for separation of polycarbonate, polyvinyl chloride and polymethyl methacrylate waste plastics by froth flotation. Waste Manag. 2017, 65, 3-10. [CrossRef] [PubMed]

110. Claessens, M.; Van Cauwenberghe, L.; Vandegehuchte, M.B.; Janssen, C.R. New techniques for the detection of microplastics in sediments and field collected organisms. Mar. Pollut. Bull. 2013, 70, 227-233. [CrossRef]

111. Nuelle, M.T.; Dekiff, J.H.; Remy, D.; Fries, E. A new analytical approach for monitoring microplastics in marine sediments. Environ. Pollut. 2014, 184, 161-169. [CrossRef]

112. Talvitie, J.; Mikola, A.; Koistinen, A.; Setälä, O. Solutions to microplastic pollution-Removal of microplastics from wastewater effluent with advanced wastewater treatment technologies. Water Res. 2017, 123, 401-407. [CrossRef]

113. Simon, M.; Vianello, A.; Vollertsen, J. Removal of $>10 \mu \mathrm{m}$ microplastic particles from treated wastewater by a disc filter. Water 2019, 11, 1935. [CrossRef]

114. Zhang, Y.; Diehl, A.; Lewandowski, A.; Gopalakrishnan, K.; Baker, T. Removal efficiency of micro-and nanoplastics (180 $\mathrm{nm}-125 \mu \mathrm{m})$ during drinking water treatment. Sci. Total Environ. 2020, 720, 137383. [CrossRef] [PubMed]

115. Wang, Z.; Sedighi, M.; Lea-Langton, A. Filtration of microplastic spheres by biochar: Removal efficiency and immobilisation mechanisms. Water Res. 2020, 184, 116165. [CrossRef]

116. Bayo, J.; López-Castellanos, J.; Olmos, S. Membrane bioreactor and rapid sand filtration for the removal of microplastics in an urban wastewater treatment plant. Mar. Pollut. Bull. 2020, 156, 111211. [CrossRef]

117. Li, L.; Liu, D.; Song, K.; Zhou, Y. Performance evaluation of MBR in treating microplastics polyvinylchloride contaminated polluted surface water. Mar. Pollut. Bull. 2020, 150, 1-6. [CrossRef]

118. Shen, M.; Song, B.; Zhu, Y.; Zeng, G.; Zhang, Y.; Yang, Y.; Wen, X.; Chen, M.; Yi, H. Removal of microplastics via drinking water treatment: Current knowledge and future directions. Chemosphere 2020, 251, 126612. [CrossRef]

119. Enfrin, M.; Lee, J.; Le-Clech, P.; Dumée, L.F. Kinetic and mechanistic aspects of ultrafiltration membrane fouling by nano-and microplastics. J. Memb. Sci. 2020, 601, 117890. [CrossRef]

120. Shen, M.; Hu, T.; Huang, W.; Song, B.; Zeng, G.; Zhang, Y. Removal of microplastics from wastewater with aluminosilicate filter media and their surfactant-modified products: Performance, mechanism and utilization. Chem. Eng. J. 2021, 421, 129918. [CrossRef]

121. Sembiring, E.; Mahapati, W.O.S.W.; Hidayat, S. Microplastics particle size affects cloth filter performance. J. Water Process Eng. 2021, 42, 102166. [CrossRef]

122. Parrish, K.; Fahrenfeld, N.L. Microplastic biofilm in fresh-and wastewater as a function of microparticle type and size class. Environ. Sci. Water Res. Technol. 2019, 5, 495-505. [CrossRef]

123. Michels, J.; Stippkugel, A.; Lenz, M.; Wirtz, K.; Engel, A. Rapid aggregation of biofilm-covered microplastics with marine biogenic particles. Proc. R. Soc. B Biol. Sci. 2018, 285, 20181203. [CrossRef]

124. Tadros, T. Electrostatic Repulsion and Colloid Stability. In Encyclopedia of Colloid and Interface Science; Tadros, T., Ed.; Springer: Berlin/Heidelberg, Germany, 2013; p. 363. [CrossRef]

125. Breite, D.; Went, M.; Thomas, I.; Prager, A.; Schulze, A. Particle adsorption on a polyether sulfone membrane: How electrostatic interactions dominate membrane fouling. RSC Adv. 2016, 6, 65383-65391. [CrossRef] 